Malin Thor Tureby*

malin.thor@mau.se

orcid.org/0000-0001-8232-8664

Department of Society, Culture and Identity

Malmö University

SE-205 06 Malmö, Sweden

Kristin Wagrell**

kristin.wagrell@liu.se

orcid.org/0000-0003-4001-0767

Tema Q, Linköpings Universitet: Campus Norrköping

SE-601 74 Norrköping, Sweden

\title{
Digitization, Vulnerability, and Holocaust Collections
}

\begin{abstract}
Although digitization has become a word that is almost synonymous with democratization and citizen participation, many museums and other cultural heritage institutions have found it difficult to live up to this political vision of inclusivity and access for all. In Sweden, political ambitions to digitize the cultural heritage sector
\end{abstract}

\footnotetext{
* Malin Thor Tureby is Professor of History at Malmö University (Sweden) and Principal Investigator (PI) of the Swedish research team for the project "Digital Heritage in Cultural Conflicts (DigiCONFLICT)" as well as the PI in other major research projects with different but related aims such as: working to produce empirically-based knowledge on how stories from different migrant groups as well as survivor testimonies and stories have been created, collected, and archived over time and collecting and writing histories about and with Jewish women in Sweden. She worked as an appointed expert to the committee of inquiry on a museum about the Holocaust in Sweden (2019-2020).
}

** Kristin Wagrell is a cultural studies scholar at Linköping University (Sweden) who recently defended her PhD thesis "Chorus of the Saved": Constructing the Holocaust Survivor in Swedish Public Discourse, 1943-1966. She is currently researching questions relating to the history of survivor activism and the archival practices of cultural heritage institutions. She is currently employed as a researcher in DigiCONFLICT and the executive editor for the interdisciplinary journal "Culture Unbound: Journal of Current Cultural Research".

The authors wish to acknowledge that this research was conducted within the framework of the JPICH Digital Heritage research project "Digital Heritage in Cultural Conflicts (DigiCONFLICT)" (EU grant agreement number: JPICH 699523). This research was conducted by and this article was written by members of the Swedish research team funded by The Swedish National Heritage Board, grant agreement number: RAÄ-2017-5067. 


\section{GENERAL ARTICLES}

Malin Thor Tureby and Kristin Wagrell

are high. Yet, institutions still struggle to reconcile their previous practices with new technologies and ethical guidelines for collecting and curating material. In this article we identify, analyse, and try to find resolutions for the current gap that exists between cultural heritage practice and government policy on digitization, open access, and research ethics. By examining two Swedish examples of Holocaust collections that have not been digitized because of internal policies of secrecy and confidentiality, we attempt to demonstrate how discourses about vulnerability affect the ways in which certain archival practices resist policies of accessibility and ethical research. In order to unpack the discourses on vulnerability, Carol Bacchi's post-structural approach to policy analysis has been used together with Judith Butler's theories on vulnerability and resistance. In addition to understanding how cultural heritage institutions in Sweden have protected some of their collections and how this has obstructed efforts to make these collections more accessible, we also offer some suggestions on how these issues can be resolved by reimagining digitization as transformation.

Keywords: Holocaust collections, vulnerability, digitization, research ethics, cultural heritage and digitalization

\section{Introduction}

During the past decade, governments and policy makers have become more ardent in their ambitions to advance the technological stature of the cultural heritage sector. Digitization has therefore become the strategy to increase public and citizen involvement in questions regarding cultural heritage. A Swedish government bill from 2017 states that the purpose of digitizing cultural heritage is to release its potential to nurture cohesion in society. Already in 2011, a national coordination secretariat (Digisam ${ }^{1}$ ) for digitalization within the cultural heritage sector was established in Sweden. In a recently published report by Digisam, entitled Digitized Cultural Heritage - For Democracy and Positive Social Change, it was reaffirmed that the digitalization of cultural heritage is fundamentally about democracy and human rights:

Cultural heritage belongs to everyone and everyone should have the same opportunities to take part in and contribute to our cultural heritage. Furthermore, cultural heritage is an important part of human history and identity and, consequently, an important part of a society's foundation. ${ }^{2}$

1 See http://www.digisam.se/digisams-nya-identitet-och-varumarke/ [accessed: 30.09.2020].

2 M. Adenfelt, I. Larsson, M. Edholm, Digitaliserat kulturarv - för demokrati och positiv samhällsutveckling. En förstudie, Digisam, Stockholm 2020, p. 8. 
In addition, the report underlined that cultural heritage institutions should collect, preserve, and make available material from groups that have been marginalized in the public discourse. Including these groups in the archiving and collecting activities initiated by Swedish institutions would, according to the report, contribute to a more inclusive writing of history. ${ }^{3}$

Although the report confirms and reconstructs the largely positive and uncritical perspective on digitalization in general that was presented in the bill from 2017, it nevertheless acknowledges that the new legal framework on digital heritage also creates substantial challenges for the actual process of digitizing cultural heritage collections. ${ }^{4}$ The primary challenges identified in the report are the absence of a unified infrastructure across cultural heritage institutions, as well as a lack in skills among archival and museum professionals with regards to digitizing and managing digital material. ${ }^{5}$ However, there are several other challenges that precede the process of digitization which need to be acknowledged and dealt with as well. For example, many collections contain information that cultural heritage institutions either wish to, or are legally obliged to protect. In this article we will present two examples that reveal challenges related to material that is considered sensitive or "vulnerable": the "Jewish Memories" (Judiska minnen) collection, and the "Memory Archive" (Minnesarkivet). ${ }^{6}$ These cultural heritage collections, containing testimonies and objects relating to the Holocaust, were created by and for two institutions that function under different legal frameworks with regards to confidentiality and anonymization; something which has greatly affected how the collections have been treated as they are both viewed as "vulnerable". This particular perception of vulnerability - intimately connected to Swedish public discourse on racism, neo-Nazism, and antisemitism in the 1980s and 1990s - has obstructed not only accessibility to these collections, but also any efforts to digitize them. In addition, "Jewish Memories", initiated in 1994 and completed in 1998, was created without the informed consent of its participants, adding another layer of complexity to an already problematic collection.

Using these examples we argue that recent Swedish policies concerning digitalization and cultural heritage (and the legal frameworks that have and will develop as a result) entail significant problems that need to be resolved before "vulnerable" collections can be digitized. As stated in the call for papers to this issue of "Santander Art and Culture Law Review" on the impact of the digital turn on cultural heritage law and policy, the application and proliferation of technology in the

\footnotetext{
3 Ibidem, p. 9. See also Kulturdepartementet, SOU 2019:58. Härifrån till evigheten: en långsiktig arkivpolitik för förvaltning och kulturarv [From Here to Eternity: A Long-Term Archiving Policy for Management and Cultural Heritage], Norstedts Juridik, Stockholm 2019, pp. 120-121.

4 Ibidem, pp. 17-18.

5 Ibidem.

6 The "Jewish Memories" collection is archived at the Nordic Museum and the "Memory Archive" was collected by the Living History Forum (Forum för levande historia) but is now archived at the National Archives (Riksarkivet).
} 


\section{GENERAL ARTICLES}

Malin Thor Tureby and Kristin Wagrell

cultural heritage sector has brought about and will bring about further substantial changes to the core of what we understand cultural heritage to be. It is transforming our idea of what heritage is, to whom it belongs, and how it should be preserved and shared. Moreover, it raises new and relevant questions about secrecy, anonymity, and informed consent.

The purpose of the research presented in this article is therefore to identify and explain some of the current contradictions and complexities that have arisen in the gap between the previous practices of cultural heritage institutions and the more recent public policy developments on digitization, open access, and accessibility. We also wish to offer our perspectives on how these problems can be resolved by understanding digitization not as a linear process of making something analogue digital, but as a process that wholly transforms a collection. In addition, the article attempts to unpack the problematizations that make ethical research on, and public accessibility to, "vulnerable" collections difficult. The use of quotation marks here is not meant to signal a fundamental questioning of the fact that the disclosure of certain information in archives can make subjects vulnerable. Rather, they are used to underscore that vulnerability is a complex concept that can be defined and perceived in multiple ways. The overarching theoretical framework guiding this research is that conceived by Judith Butler in her writings on vulnerability. ${ }^{7}$ We also make use of Carol Bacchi's "What's the problem represented to be?" approach ${ }^{8}$ to understanding how practices of, and policies on, confidentiality and anonymization have both formed and subsequently affected the conditions for digitization.

Our arguments are presented in six sections. We begin by elaborating on the concept of vulnerability, with a focus on Butler's notions of infrastructural support and agency. In the same section we also explain how Bacchi's approach has aided us in our aim to unpack the underlying problematizations of confidentiality and secrecy and their effects on efforts to make "vulnerable" collections more accessible. In the second section we discuss how anonymity and confidentiality have been treated in commemorative practices pertaining to the Holocaust outside of Sweden, focusing on practices involving naming and individualization. As these practices contrast with the Swedish case, we also attempt to unpack media discourses on racism, neo-Nazism, and antisemitism during the 1980s and 1990s in order to answer the question of why Holocaust collections have been protected and anonymized in Sweden. In the next two sections, we present the two cases and explain how each one represents a different way in which cultural heritage institutions have dealt with increasing pressures to digitize their collections. Finally, we offer a suggestion on how the problems that have arisen in the gap between cultural

7 J.Butler, Precarious Life. The Powers of Mourning and Violence, Verso, London-New York 2006 and eadem, Rethinking Vulnerability in Resistance, in: J. Butler, Z. Gambetti, L. Sabsay (eds.), Vulnerability in Resistance, Duke University Press, Durham 2016.

8 C. Bacchi, Analysing Policy. What's the Problem Represented to Be?, Pearson, Frenchs Forest, N.S.W. 2009. 
heritage practice and public policy on digitization can be resolved by reconceptualizing digitization as transformation. This section deals with ideas and arguments that are part of a greater project currently under development. It is therefore not meant to provide an answer to the complex problems presented in this article, but rather constitutes a first step in attempting to bridge the gap between cultural heritage practice and policies of digitization and open access.

\section{The "Jewish Memories" Collection and the "Memory Archive": A Background}

The Nordic Museum is Sweden's first, largest, and most influential cultural heritage institution. "Jewish Memories" - created at the museum in the mid-1990s - comprises approx. 400 oral and written testimonies, 1,600 photographs, and 100 objects. In sheer size it is one of the most significant Swedish holdings of Holocaust memory. Even though the collection was created to counter voices from neo-Nazi groups and right-wing extremists, it remains protected by a 70-year protection clause, which means that anyone who wants access to the material has to apply for special permission from the Nordic Museum. ${ }^{9}$ By referring to the Personal Data Act of $1998,{ }^{10}$ the Museum wishes to protect what they consider to be "vulnerable" subjects in the collection. Other than the Jewish identity of the interviewed subjects, what this vulnerability consists of has never been further specified. Furthermore, the life stories in the collection were collected without the informed consent of the participants as to their future use; an aspect that further complicates their digitization or any scholarly scrutiny of the collections and its documents. At the same time, being one of the most extensive collections of Holocaust memory in Sweden it constitutes an invaluable source for individuals and researchers interested in Swedish-Jewish identity, Holocaust survival (both during and after the Holocaust), and more generally, discourses and practices surrounding Holocaust memory.

A year after "Jewish Memories" had been finalized, a new collection effort concerning Holocaust testimonies and objects began under the auspices of the "Living History" project. During the process of creating "Jewish Memories", the then Swedish Prime Minister, Göran Persson launched an informational campaign called "Living History". The campaign was initiated as a response to a survey conducted by the Swedish National Council for Crime Prevention (Brottsförebyggande rådet, BRÅ) and Stockholm University, which showed that almost a third of the young

\footnotetext{
9 Although the Nordic Museum is a foundation and not a governmental institution, this 70 -year protection clause refers to Sekretesslag (1980:100) [Secrecy Act], Svensk författningssamling 1980:100 and Offentlighets- och sekretesslag (2009:400) [Public Access to Information and Secrecy Act], Svensk författningssamling 2009:400. These laws concern the handling of public documents by public authorities and certain other bodies in the registration, disclosure, and other handling of public documents. For further reading on this topic, see the article referenced in footnote 70.

10 Personuppgiftslag (1998:204), Svensk författningssamling 1998:204.
} 


\section{GENERAL ARTICLES}

Malin Thor Tureby and Kristin Wagrell

respondents had little knowledge about the Holocaust and that a significant percentage denied that the Holocaust had ever occurred. ${ }^{11}$ Even though the survey turned out to be flawed with regards to these particular results, the campaign led to several national and transnational commemorative and educational initiatives relating to the Holocaust: the founding of an International Taskforce for Holocaust Remembrance (ITF) in 1998; the Stockholm International Forum Conferences between 2000 and 2004; and the establishment of a Swedish government agency in 2003 titled the Living History Forum (LHF). ${ }^{12}$ Part of the preparatory work that was conducted for the new institution that would later become the LHF was a collection of memories from the time of the Holocaust. This endeavour resulted in the "Memory Archive", a collection that contains over 100 video-taped testimonies from individuals with a connection to the Holocaust (e.g. victims, rescue workers, and bystanders). Even though a majority of the interviewed subjects were neither Jewish nor Holocaust survivors, the collection was deemed "vulnerable" and the committee in charge of the collection process - working under the authority of the Ministry of Culture - applied for a special exemption from the principle of public access to information and secrecy. This was, however, revoked and the collection is now kept on hard drives at the LHF's main premises in Old Town, Stockholm as well as at the Swedish National Archives. The material has not been indexed and there is, therefore, no catalogue of the interviews. Rather, it seems as if the collection has been hidden from view so as not to draw attention to itself.

What is interesting about the protectionist measures that have been taken with regards to these Holocaust collections is that they in many ways defy a larger, transnational trend within Holocaust archiving, commemoration, and education; a trend that emphasizes acts of naming, individualization, and transparency. Sweden thus stands out as an exception with regards to the protection of archival holdings related to the Holocaust. Furthermore, in the governmental declaration of 2019, the Swedish Prime Minister, Stefan Löfven, stated that "a museum to preserve the memory of the Holocaust" should be established in Sweden; a project in which Holocaust survivor testimonies were avowed to be crucial. ${ }^{13}$ As there are few survivors left to testify in a new collection, investigations have been made concerning the already-existing collections and their inclusion into the activities of the prospective museum. Yet, how will this be possible when Swedish institutions guard what

11 A. Lange et al., Utsatthet för etniskt och politiskt relaterat hot mm., spridning av rasistisk och antirasistisk propaganda samt attityder till demokrati $\mathrm{mm}$. bland skolelever [Exposure to Ethnically and Politically Motivated Violence, the Spread of Racist and Anti-Racist Propaganda, and Attitudes to Democracy Among School Youth], Ceifo, Stockholm 1997, p. 56.

12 L. Allwork, Holocaust Remembrance Between the National and the Transnational: The Stockholm International Forum and the First Decade of the International Task Force, Bloomsbury Publishing, London 2015.

13 Regeringen, Regeringsförklaringen [Governmental Declaration], 21 January 2019, https://www.regeringen.se/48f68a/contentassets/6e0630547665482eaf982c4777f42f85/regeringsforklaringen-2019.pdf [accessed: 15.01.2020]; English summary: http://www.sou.gov.se/mof/in-english/ [accessed: 28.09.2020]. 
they consider to be "vulnerable" material? Also, in attempts to protect "vulnerable" subjects, large-scale and important collection projects have lost momentum and come to naught. This is evidenced by "Roma Memories", a planned collection of testimonies from Roma survivors of the Holocaust that was to be part of the "Memory Archive" but which was abandoned as the material could not be protected.

The main questions governing our analysis are therefore: What is it that makes these collections particularly vulnerable in a Swedish context? How can we understand the effects of these protective measures? And how do we bridge the gap between the institutional practice of confidentiality and secrecy and further calls for digitization and open access? Before we can begin to address any of these questions, however, the notion of vulnerability needs to be expounded further.

\section{The Problem of Vulnerability}

Vulnerability is a complex concept that can be defined and perceived in multiple ways. The definition of "vulnerability" varies in and between disciplines, research fields, and national legislations, although several interdisciplinary projects have recently been launched that fundamentally engage with the theories and methodologies surrounding vulnerability, knowledge production, and accessibility. ${ }^{14}$ Previous research and these ongoing projects have underlined - and continue to underline the constructedness of vulnerability and the ways in which these constructions affect archival subjects' ability to act in resistance of that which oppresses them. These perspectives, in part, borrow from the gender scholar and theorist Judith Butler's conceptualizations of vulnerability. According to Butler, vulnerability occurs as a result of the corrosion, removal, or destruction of "infrastructural support" - e.g. access to food, shelter, or a voice in the public sphere - as well as through the creation of "linguistic vulnerabilities". ${ }^{15}$ Butler explains the latter by declaring that:

[...] we do not only act through the speech act; speech acts also act on us. There is a distinct performative effect of having been named as this gender or another gender, as part of one nationality or a minority, or to find out that how you are regarded in any of these respects is summed up by a name that you yourself did not know and never chose. ${ }^{16}$

Connected to these "linguistic vulnerabilities" are the social, cultural, economic, political, and legal vulnerabilities that come about when there is little or no "infrastructural support". This concept is described by Butler as something which includes both the material things humans need to survive, as well as the spaces and

14 D. Agostinho et al., Uncertain Archives: Approaching the Unknowns, Errors, and Vulnerabilities of Big Data through Cultural Theories of the Archive, "Theories of the Archive, Surveillance and Society" 2019, Vol. 17(3-4), p. 423. See also http://www.engagingvulnerability.se/ [accessed: 06.10.2020].

15 J. Butler, Rethinking Vulnerability..., pp. 12-19.

16 Ibidem, p. 16. 


\section{GENERAL ARTICLES}

Malin Thor Tureby and Kristin Wagrell

networks that allow for political action. For example, Butler argues that "media can function as part of 'infrastructural support' when it facilitates modes of solidarity and establishes new spatio-temporal dimensions of the public sphere". ${ }^{17}$ One of the problems with seeing vulnerability as a state of passivity, however, is that it overlooks all the ways in which vulnerability can mobilize. Butler argues that once groups are "marked as 'vulnerable' within human rights discourse or legal regimes, those groups become reified as definitionally 'vulnerable', fixed in a position of powerlessness and lack of agency". ${ }^{18}$ This does not mean that vulnerable individuals and groups do not need help, but rather that a paternalistic protection of them obscures perspectives on how "vulnerability enters into agency". ${ }^{19}$

As survivor testimony continues to be a central genre of Holocaust studies, perspectives that pertain to how, and for whom, Holocaust stories are told also highlight problems that relate to vulnerability, digitization, and accessibility. Henry Greenspan has, for example, pioneered studies of oral narratives from the Holocaust by questioning the very concept of testimony itself; contending that the act of listening to Holocaust survivors never involves the extraction of truth from living subjects, but rather, constitutes a dialogic exchange through which the interviewer and interviewee find new ways of remembering together. Therefore, for the past 40 years, Greenspan has had numerous and continuous conversations with the same survivors in order to understand how they "recount" the Holocaust within a conversation. ${ }^{20}$ Although Greenspan does not use vulnerability as a concept in his research, his work still contributes invaluable insights into the making of Holocaust collections - of how interview subjects always begin by telling what they believe that the listener expects, and how certain historical narratives multiply not because they hold a universal truth about the past, but because the collective memory protocols of what Holocaust history is and, indeed, should be, significantly shape them. These insights, in turn, inform our understanding of vulnerability as something that comes to be in both the process of planning for a collection as well as during the collecting process itself.

In order to grasp this discursive embeddedness of vulnerability, we have used Carol Bacchi's "What's the problem represented to be" (WPR) approach to unpack the problematizations that underpin perceptions on the vulnerability of Holocaust collections in Sweden. WPR is a post-structural analytical tool-box that helps policy researchers understand which problematizations or problem representations that policies are founded on and how these problem complexes and the resulting policies disenfranchise and harm certain groups while benefit-

$17 \quad$ Ibidem, p. 14.

18 Ibidem, p. 29.

19 Ibidem, p. 25.

20 H. Greenspan, On Listening to Holocaust Survivors. Beyond Testimony, 2nd ed., Paragon House, St. Paul, MN 2010, p. 3. 
ing others. ${ }^{21}$ Rather than unpacking a particular policy, we will use Bacchi's WPR approach to understand how two different institutions - a foundation (the Nordic Museum) and a government agency (the Living History Forum) - have interpreted the Swedish legal framework on public access and secrecy to protect their Holocaust collections. We have chosen to use Bacchi's post-structuralist approach because it allows us to be sensitive to both cause and effect; i.e. how discourses and their underlying assumptions have real effects on peoples' lives. ${ }^{22}$ WPR is based on basic questions that can be asked about the material at issue: What's the problem represented to be in a specific policy? What presuppositions or assumptions underlie this representation of the "problem"? How has the representation of the "problem" come about? What is left unproblematic in this problem representation? Where are the silences? Can the "problem" be thought about differently? What effects are produced by this representation of the "problem"? How/where is this representation of the "problem" produced, disseminated, and defended? And how could it be questioned, disrupted, and replaced? ${ }^{23}$

These three final questions are particularly important to our study as they reiterate Butler's concern about finding the ways in which vulnerability can become agentic. In the following sections we will thus attempt to identify the main problem representations underpinning the confidentiality and secrecy policies surrounding Holocaust collections in Sweden, explain how these problem representations developed and, finally, try to question, disrupt, and replace these representations in order to bridge the gap between cultural heritage practice and governmental policy on digitization and open access.

\section{Anonymity as Vulnerability in Holocaust Collections}

Niamh Moore writes that anonymity is a key concern when ethics is discussed in relation to research, and is often deemed an essential, self-evident principle for protecting research participants from possible harm. Anonymization, i.e. the process of guaranteeing anonymity through the exclusion of research participants' names, is also commonly presented as the standard technical practice to meet this end. ${ }^{24}$ Implicitly, anonymization is a practice carried out to avoid causing harm. Also implicit is the reverse assumption - that naming is dangerous. There is thus an assumption that we can avoid harm and "protect" research participants by avoiding the use of their names. ${ }^{25}$ But Moore suggests that we need to locate anonymity

21 See, for example, C. Bacchi, S. Goodwin, Poststructural Policy Analysis: A Guide to Application, Palgrave Macmillan, London-New York 2016.

22 C. Bacchi, Analysing Policy..., p. 48.

23 Ibidem.

24 N. Moore, The Politics and Ethics of Naming: Questioning Anonymisation in (Archival) Research, "International Journal of Social Research Methodology" 2012, Vol. 15(4), p. 332.

25 Ibidem. 


\section{GENERAL ARTICLES}

Malin Thor Tureby and Kristin Wagrell

in time, rather than assuming it as an ahistorical ethical norm. As she points out, "[...] for much of history anonymity did not protect the vulnerable but excluded women and others from authorship and ownership of their own words, erasing them from the archive, even from history, and in the process creating vulnerability through rendering people nameless". ${ }^{26}$ With these words, Moore reminds us that the seemingly a priori association of anonymity with protection, and naming with harm, can and, indeed should be, questioned. Moore's insights on erasures and the archive are neither novel nor innovative in and of themselves. Rather, it is her critical examination of anonymization in relation to the methodological practices of archiving and the reuse of already-established collections that significantly contributes to discussions on anonymization as an ethical problem.

Although several studies of Holocaust archival processes have been published in the last decade, none of the authors discuss the issues of anonymity and vulnerability in relation to collecting and curating testimonies and objects. ${ }^{27}$ While Australian Holocaust scholar Noah Shenker problematizes the underlying epistemologies of American Holocaust collections, questions regarding anonymization and protection of privacy are never dealt with. Indeed, it appears that the ethical and methodological issues concerning vulnerability and anonymity that have been identified within other research fields have never been broached within Holocaust studies. Rather, in Holocaust studies vulnerability has been understood in relation to the ethical imperative to give and listen to testimonies. Following the philosophy of Emmanuel Levinas, Holocaust scholars have underlined ethics as an issue arising from vulnerability - about the recognition of the face, of the "relation with the Other", of seeing and hearing the Other - perhaps most salient in establishing a relationship between the survivor and the audience. ${ }^{28}$

Consequently, several memory institutions dedicated to research and remembrance of the Holocaust have made it their priority to individualize the victims by trying to collect the names of each victim of the Holocaust. The Shoah Victims' Names Recovery Project at Yad Vashem ${ }^{29}$ aims, for example, to memorialize each individual Jew murdered in the Holocaust by recording their names, biographical details, and photographs. ${ }^{30}$ Since 1955, Yad Vashem has been fulfilling its mandate to preserve the memory of Holocaust victims by collecting their names, which is

\footnotetext{
26 Ibidem.

27 See, for example, S. De Jong, The Witness as Object. Video Testimonies in Memorial Museums, Berghahn Books, New York 2018; J. Shandler, Holocaust Memory in the Digital Age. Survivors' Stories and New Media Practices, Stanford University Press, Stanford, CA 2017; N. Shenker, Reframing Holocaust Testimony, Indiana University Press, Bloomington, IN 2015.

28 E. Levinas, Totality and Infinity. An Essay on Exteriority, Duquesne University Press, Pittburg 1969.

29 The name of the institution in itself underlines the importance of names in Jewish tradition, as it is written: "And to them will I give in my house and within my walls a memorial and a name (Yad Vashem), an everlasting name that shall not be cut off" (Isaiah 56:5).

30 Yad Vashem, Names Recovery Project, https://www.yadvashem.org/remembrance/names-recoveryproject/about.html [accessed: 30.09 .2020$]$.
} 
motivated by the fact that the name is "the ultimate representation of a person's identity". Through these efforts, Yad Vashem "hope[s] to return to the victims their names and faces and thus to thwart the stated Nazi intention of murdering them and wiping out their memory". 31

The Central Database of Shoah Victims' Names currently contains 4.8 million names in its Pages of Testimony. The first 800,000 names in Pages of Testimony were collected during the 1950 s, with continuing worldwide outreach attempts to identify the unnamed victims of the Shoah so they will forever be remembered. A "Room of Names" was opened in 1968 at Yad Vashem as an archive for the original handwritten Pages of Testimony. In 1977 the "Hall of Names" was inaugurated in a specially designed building, and when the institution established the new Holocaust History Museum complex in 2005 it included a newly designed "Hall of Names". The "Hall of Names" curates the original pages of testimonies, while the Central Database of Shoah Victims' Names offers, through the Yad Vashem website, full and free accessibility to close to 3 million victims' names. ${ }^{32}$

The purpose of Yad Vashem's initiative is thus to give the victims back their names and identity, something that was taken from them when they were, for example, reduced to numbers tattooed into their arms in Auschwitz, and later murdered, burned and placed in mass graves without tombstones. ${ }^{33}$ Another project that highlights the names and individual fates of the victims is the artist Gunter Demning's Stolpersteine (stumbling stones). ${ }^{34}$ Although the project started in the $1990 \mathrm{~s}$ to commemorate Roma and Sinti victims of the Holocaust, Demning often quotes the Talmud: "A person is only forgotten when his or her name is forgotten" - in interviews about the project. ${ }^{35}$ Today, over 70,000 stones have been laid commemorating individuals from all the different victim groups persecuted by the Nazis. ${ }^{36}$ Further, there has been a continuous endeavour to make their testimonies available and accessible to the public and researchers in line with technological developments. ${ }^{37}$ One example is the The Arolsen Archives, which at the beginning of 2020

\footnotetext{
31 Yad Vashem, Shoah Victims' Names, https://www.yadvashem.org/archive/hall-of-names/shoah-victims-names.html [accessed: 30.09.2020].

32 Yad Vashem, Hall of Names, https://www.yadvashem.org/archive/hall-of-names.html [accessed: 30.09.2020].

33 I.M. Nick, Personal Names, Hitler, and the Holocaust. A Socio-Onomastic Study of Genocide and Nazi Germany, Lexington Books, Lanham, MD 2019.

34 Stolpersteine are concrete blocks which are laid into the pavement in front of the last voluntarily-chosen places of residence of the victims. Their names and fate are engraved into a brass plate on the top of each Stolperstein.

35 See, for example, E. Apperly, "Stumbling Stones": A Different Vision of Holocaust Remembrance, "The Guardian", 18 February 2019, https://www.theguardian.com/cities/2019/feb/18/stumbling-stones-a-different-vision-of-holocaust-remembrance [accessed: 30.09.2020].

36 See https://www.stolpersteine-berlin.de/en [accessed: 30.09 .2020$]$.

37 Another example is The Fortunoff Video Archive for Holocaust Testimonies at Yale University.
} 


\section{GENERAL ARTICLES}

Malin Thor Tureby and Kristin Wagrell

launched the crowd-sourcing project "every name counts" through social media. Their primary goal was to ensure that all the names in the millions of documents stored in the Arolsen Archives could be searched and found on their online platform, and that people all over the world could easily access information about the fate of their relatives. The project is also referred to as a "unique digital monument". ${ }^{38}$

The above examples illustrate the importance of recalling the names of the murdered 6 million in commemoration of the Holocaust, as well as the millions of others who were persecuted by the Nazis. There are also other examples that demonstrate that survivors of the Holocaust have been treated in a similar manner. For example, the digitization of the USC Shoah Foundation's Visual History Archive allows users to search through and view more than 54,000 video testimonies of survivors and witnesses of genocide. ${ }^{39}$ Here the witnesses or survivors are presented together with their names, photos, and videos. The terms of use also require that when one is referring to the archive testimonies, one should "include the author - in this case, the name of the interviewee(s)".$^{40}$ Hence, the importance of giving the victims their names back, as well as the importance of offering the survivor the opportunity to formulate his/her own subjective and personal testimony, has permeated the approaches of several memory institutions and their methodologies when working with Holocaust memory.

In an international context, outside Sweden, the collecting and digitizing of Holocaust archives has thus attempted, with the help of rapidly evolving digital technologies, to make testimonies, documents, and names available and accessible. The ethical imperative is to give both the murdered and the survivors a face and a name. However, Sweden's archival institutions have not been part of this movement. In Sweden, "Jewish Memories" remains hidden, inaccessible to the general public and to researchers without permission to study the material. The people who have left their stories remain anonymous and their names, stories, and testimonies are not heard in public or used by researchers. Similarly, the Living History Forum's "Memory Archive" lies untouched, with no efforts being undertaken to make it more accessible to the public or to Swedish and international researchers. Furthermore, the work that went into planning and fighting for a collection of Roma survivor testimonies was all in vain and their voices remain silent forever. This concealment and silencing of survivor voices in Sweden can, to some extent, be explained by the ways in which personal integrity and research ethics are regulated by law. Therefore, in the following section we explore some of these legal frameworks.

38 Arolsen Archives, Help Us Build a Unique Digital Monument, https://arolsen-archives.org/en/learn-participate/interactive-archive/everynamecounts/ [accessed: 28.09.2020].

39 See https://vhaonline.usc.edu/login [accessed: 30.09.2020].

40 USC Shoah Foundation's Visual History Archive, Terms of Use, https://vhaonline.usc.edu/TermsOfUse [accessed: 09.10.2020]. 


\section{Vulnerability and Research Ethics in Swedish Law}

In Sweden, over the last two decades, research ethics in the humanities and social sciences has been regulated by Swedish law. One of these laws was adopted in 2004 and regulates ethical vetting procedures for all research that involves humans. It thereby encompasses research involving living people, but also covers such areas as research on those who are deceased, biological material from people, and research that involves dealing with sensitive information about people or personal information concerning offences against the law. ${ }^{41}$ The legal text explains that "the purpose of the law is to protect the individual and the respect for human dignity in research". ${ }^{42}$ The Swedish law concerning research ethics is in many ways informed by the WMA Declaration of Helsinki, and is therefore subject to biomedical science's epistemological standards, concepts, and discourses about who are considered to be "vulnerable groups". ${ }^{43}$ Furthermore, with the law on research ethics also came standardized research-ethics regulations and application forms, and the establishment of central and local ethical vetting boards charged with the mission to consider and approve or disapprove applications. ${ }^{44}$ Memory institutions like archives and museums often refer to the law of secrecy or laws concerning personal data for secrecy with regards to a certain named person. ${ }^{45}$

Furthermore, on 1 January 2019 a special state agency, the Ethical Review Authority (Etikprövningsmyndigheten), was founded in Sweden in order to ensure that all research follows the ethical standards inscribed in the Act (2003:460) Concerning the Ethical Review of Research Involving Humans. ${ }^{46}$ This means that research that deals with human subjects in Sweden needs to be approved by an ethical vetting board, while collections that are created by cultural heritage institutions do not need approval from any national governing body. This, in turn, means that the digitization and/or reuse of archival material from institutions like the Nordic $\mathrm{Mu}$ seum or the Living History Forum often come with already embedded ethical issues that cannot be understood without further inquiry into past processes of collection and curation. The current gap or conflict between the practices of cultural heritage institutions and those of humanist and social scientific research is also further

41 Etikprövningsmyndigheten, Vetting the Ethics of Research Involving Humans, http://www.epn.se/en/ start/ [accessed: 14.08.2020]; Lag (2003:460) om etikprövning av forskning som avser människor [Act Concerning the Ethical Review of Research Involving Humans], Svensk författningssamling 2003:460.

42 Act (2003:460) Concerning the Ethical Review of Research Involving Humans, para. 1.

43 WMA Declaration of Helsinki - Ethical Principles for Medical Research Involving Human Subjects, adopted in June 1964, https://www.wma.net/policies-post/wma-declaration-of-helsinki-ethical-principlesfor-medical-research-involving-human-subjects/ [accessed: 29.11.2020].

44 Etikprövningsmyndigheten, op. cit.

45 Public Access to Information and Secrecy Act (2009:400); Personal Data Act (1998:204); and Lag (2018:218) med kompletterande bestämmelser till EU:s dataskyddsförordning [Act Containing Supplementary Provisions to the EU General Data Protection Regulation], Svensk författningssamling 2018:218.

46 Etikprövningsmyndigheten, op. cit. 


\section{GENERAL ARTICLES}

Malin Thor Tureby and Kristin Wagrell

exacerbated by the fact that the research ethical vetting boards' review processes are underpinned by biomedical epistemologies that emphasize the importance of anonymization of vulnerable subjects. ${ }^{47}$ As scholars have shown within other national and international contexts, anonymization - although important to protect life and dignity - causes erasures in the historical record and disenfranchizes different groups as much as it protects them from harmful exposure. ${ }^{48}$ It thus seems that the institutionalization of research ethics in Sweden has not helped resolve the issues that most humanities and social scientific researchers confront when working with material contributed by living subjects. Also, this tendency to protect and anonymize stands in stark contrast with the simultaneous pressures for open access and public availability in the publication of research as well as in the digitization of cultural heritage collections. Thus, there are at one and the same time two substantive and contradictory discursive strains that fundamentally affect the way "vulnerable" cultural heritage collections can be reused for research purposes.

\section{"The Swastika Is Seen Again, Sieg Heil Echoes on Our Streets, Neo-Nazis Are Marching": The Problem that Created the Swedish Exception}

Even though the above discussion of the Swedish legal frameworks on secrecy, anonymization, and research ethics demonstrates how cultural heritage institutions can protect their collections, it does not elucidate why. So, the question that remains is why Swedish cultural heritage institutions seem more concerned about the anonymity of both Jewish and Roma survivors than their North American, Israel, and European counterparts?

The quotation in the heading above is taken from a speech that Prime Minister Persson gave in 1997 to the Swedish parliament as a response to a survey showing the extent to which Swedish youth were unaware of, and/or denied, the Holocaust. In his speech, Persson framed the neo-Nazi threat as a political and ideological alien force that was attempting to take over society by corrupting Swedish youth. The neo-Nazis were able to do this, argued Persson, because young people in the 1990s had not experienced the Second World War first-hand and therefore could not comprehend the catastrophic consequences that followed in the wake of Nazi propaganda. ${ }^{49}$ This representation of the problem was not formulated

47 M. Thor Tureby, Makten över kunskapsproduktionen. Den institutionaliserade etikprövningen och humanistisk och kulturvetenskaplig forskning [The Power over Knowledge Production. Institutionalized Ethical Vetting and Humanistic and Cultural Studies], "Kulturella Perspektiv. Svensk etnologisk tidskrift" 2019, Vol. 28(1-2), pp. 17-29.

48 C. Le Roux, Oral History Research Ethics: Should Anonymity and Confidentiality Issues Be Dealt with on Their Own Merit?, "Africa Education Review" 2016, Vol. 12(4), pp. 552-566; N. Moore, The Politics..., pp. 331-340. 49 Minutes of the Riksdag 1996/97:119, 12 June 1997, p. 22, https://data.riksdagen.se/fil/62A0CA5E31EE-4431-BE69-BA7A41688D2A [accessed: 26.10.2020]. 
in a vacuum, but had developed over the course of two decades with televised and printed news reports and articles presenting the neo-Nazi, racist, and antisemitic threat as something new, marginal, yet increasingly dangerous and threatening to inherent Swedish values of democracy and equality.

During the 1980s and early 1990s, a few key events helped construct an image of racism and neo-Nazism as phenomena that had begun to plague Swedish society. Swedish historian Helene Lööw argues that before 1980 racism was viewed as a foreign issue; a problem that existed in places like the United States and South Africa but that was considered wholly absent in Swedish society. ${ }^{50}$ This perception changed, however, during the 1980s with the establishment of the racist organization Bevara Sverige Svenskt (BSS, Keep Sweden Swedish) and a series of violent actions undertaken by Nazisternas Riksparti (NRP, The National Nazi Party), both of which garnered much media attention. ${ }^{51}$

Simultaneously, another threat was detected when the Moroccan-Swedish media figure, Mohammed Rami, was sentenced to six months in prison for antisemitic defamation disseminated through his radio channel, Radio Islam. As media scholar Heike Graaf explains, "before the verdict of 1989, there was little to no interest in the daily press to communicate the media offers by Radio Islam, or at least opinions about them". ${ }^{52}$ After the verdict, however, the Swedish mainstream media contributed to the construction of Rami as, in Graaf's words, "the personified other". ${ }^{53}$ In contrast to racist and neo-Nazi violence, Rami's antisemitism was viewed as "twice as perilous" since he was both an immigrant (meaning that he could be characterized as a foreign, outside threat) and an anti-Semite, and therefore represented a danger that was previously unknown to Swedish society. ${ }^{54}$ According to Graaf, this also made Rami an erratic and unpredictable figure, whose capriciousness made him an even greater threat than domestic neo-Nazi individuals and groups. Quoting an article in the evening newspaper "Expressen", she explains that "the danger [of Rami]" was perceived as "incalculable. The other is personified uncertainty and cannot be measured with common criteria. Rami is both civilized and primitive, intelligent and foolish, which distinguishes him from people who are easy to see through". ${ }^{55}$

50 H. Lööw, Nazismen i Sverige, 1980-1999 - den rasistiska undergroundrörelsen: musiken, myterna, riterna [Nazism in Sweden, 1980-1999 - The Racist Underground Movement: Music, Myths, and Rites], Ordfront förlag, Stockholm 2000, p. 24.

51 Ibidem, pp. 30-62.

52 H. Graaf, How Do Mainstream Media Communicate Minority Media? A Difference-Theoretical Study on Radio Islam and AYPA-TV, Södertörns högskola, Huddinge 2009, p. 23.

53 Ibidem, p. 26.

54 Ibidem, pp. 27-29.

55 Ibidem, p. 29. 


\section{GENERAL ARTICLES}

Malin Thor Tureby and Kristin Wagrell

This "incalculable" threat, although difficult to predict, was nevertheless not framed as something that was common to, or pervasive in, Swedish society. Rami was a lone ranger that had been disciplined by Swedish norms through the judicial system. Neo-Nazi groups and organizations were, in similar ways, also described and depicted in the early 1990s as deviations from the norm; organizations whose ideas and values could be staved off and contained. In her study of Swedish television's reporting on racism and anti-racism in the late 1980s and early 1990s, the sociologist Birgitta Löwander contends that "racist violence was understood as a deviation from the normal, that is, as something abnormal and sick. With the metaphor of sickness, racism could also be understood as something contagious that could be spread, especially among the young and innocent". ${ }^{56}$ Furthermore, according to Löwander, racism was never framed as something performed by all Swedes in different ways or at different levels, but as something that was performed by lonely madmen or a few "maladjusted skinheads". ${ }^{57}$ At the same time, Löwander continues, immigrants and others who were targeted by neo-Nazi and racist violence were framed as passive victims. In this way they were considered incompetent to defend or care for themselves and were never allowed to speak about the violence that affected them, but were only asked to comment on and convey their own fears and vulnerable positions..$^{58}$

Interestingly, very few differentiations were made in the Swedish news discourse between racism, xenophobia, and antisemitism. They were all seen as the product of a few pathologically angry individuals who were bent on wreaking havoc on Swedish democracy and equality. However, Swedish antisemitism has, according to antisemitism scholar Henrik Bachner, been largely consistent across the decades after 1945, with some novel influences "emanating from parts of the Muslim world" in the late 20 th and early 21 st centuries. ${ }^{59}$ This means that antisemitic ideas and discourses did not become a threat owing to the conviction of Rami in 1989 or the formation of groups such as BSS and VAM, but has existed in several different forms long before these organizations were formed. Also, Bachner demonstrates that although the trial of Rami and the revocation of his radio license in 1989 silenced many of his supporters, Radio Islam had attracted "significant support from a number of well-known journalists, intellectuals and academics, many of whom were outspoken anti-zionists, who claimed that Radio Islam was nothing but

56 B. Löwander, Rasism och antirasism på dagordningen - studier av televisionens nyhetsrapportering i början av 1990-talet [Racism and Anti-Racism on the Agenda - Studies of Television News Reporting in the Early 1990s], "Sociologisk forskning" 1998, Vol. 35(3-4), p. 94.

57 Ibidem, p. 93.

58 Ibidem, p. 95.

$59 \mathrm{H}$. Bachner, Political Cultures of Denial? Antisemitism in Sweden and Scandinavia, in: L. Rensman, J.H. Schoeps (eds.), Politics of Resentment: Antisemitism and Counter-Cosmopolitanism in the European Union, Brill, Leiden 2011, p. 329. See also idem, Återkomsten. Antisemitism i Sverige efter 1945 [The Return. Anti-Semitism in Sweden after 1945], Natur \& Kultur, Stockholm 1999. 
a pro-Palestinian voice expressing legitimate criticism against Israel and Zionism".60 Yet, this support was rarely problematized in the Swedish press as a threat against the Swedish-Jewish minority. Bachner explains this culture of denial thusly:

The culture of denial in Sweden is complex. Its causes and functions must be understood against the background of several factors. One important factor is the national self-image that was constructed during the post-war era. This was a self-image from which problematic elements of the recent past - pro-German sympathies during the 1930s and the war years, cooperation with the Nazi regime, racial biology, eugenics, and antisemitism - had been erased or rendered a place of little importance. Antisemitism was reconstructed as a foreign, particularly German, phenomenon or as an element isolated to marginal Nazi groups. Manifestations of antisemitism within the broader political culture represented and continue to represent a challenge to this image. It is not supposed to exist and must therefore be denied, or at least trivialized. ${ }^{61}$

While racism was viewed as an international phenomenon before 1980 , antisemitism is still considered un-Swedish and something that can primarily be found in marginal groups that have anomalous authoritarian perspectives on society and wish to harm minorities and spread dissent. These views have, since the late $1980 \mathrm{~s}$ and early 1990s, become common sense notions about what racism and xenophobia are in Sweden today. Rather than understanding them as discourses and practices that permeate the entire social body, they are seen as specific threats that can be, if not completely thwarted, then at least mitigated through protective measures adopted by the government and other social, cultural, economic, and political institutions.

Therefore, Jewish and Roma vulnerability was, and still is, viewed as something that can be eliminated if these groups are protected from the deviant figures that threaten them. Rather than accepting that Jewish and Roma vulnerability is dependent on many different factors - pervasive antisemitism and xenophobia, policing, economic policy, and historiographical and cultural marginalization to name but a few - Swedish institutions view them solely as potential victims of explicitly neo-Nazi and xenophobic individuals and organizations.

\section{"Jewish Memories" - Creating a Collection without Informed Consent}

The notion that Jewish survivors and Swedish Jews could be protected from neo-Nazis and other racist and xenophobic organizations was also pervasive in the planning, collecting, and archiving process of "Jewish Memories". Malin Thor Tureby has, in previous publications, discussed the initiation and archivization of the

60 H. Bachner, Political Cultures..., p. 332.

61 Ibidem, pp. 354-355. 


\section{GENERAL ARTICLES}

Malin Thor Tureby and Kristin Wagrell

collection "Jewish Memories" in relation to the dominant discourses on Jewishness in Sweden in the 1990s. Hence we will only very briefly discuss these processes in this text. ${ }^{62}$ In the following section we will, instead, focus on how ethics was discussed (or not) and practiced during the collecting process, and what consequences these considerations had later on for the curating process surrounding "Jewish Memories" and, by extension, the vulnerability of the Jewish participants.

The prologue to the collection was an idea to create an exhibition in 1995 on the occasion of the 50th anniversary of the so-called "White Buses mission". ${ }^{3}$ The initial intention behind the exhibition was thus to collect memories from as many people as possible in order to create a memory archive about Sweden during the Second World War. However, when the museum decided to initiate the collection, the focus shifted to a Jewish perspective on the Second World War. ${ }^{64}$ The impetus to focus only on a Jewish perspective and not on Swedish memories from the war in general was motivated by the perceived need to quell the voices that claimed that the Holocaust never occurred and to counteract an increase in xenophobia and antisemitism in Swedish society. The idea was that "a documentation of Jewish memories would [...] be a very important contribution and a tool in the fight against xenophobia and racism". ${ }^{65}$ Therefore, one could argue that the Jews, or the Jewish survivors often categorized as "vulnerable", were assigned a mission here; to save a vulnerable Swedish society from a perceived increase in racism and xenophobia. ${ }^{66}$

Quite early in the process, it was decided that the documentation should concern three categories of people: Jews who were born in Sweden; Jews who fled to Sweden before and during the war; and Jews who came to Sweden from concentration camps. An interview guide and/or questionnaire was constructed to be used either while interviewing all three constructed Jewish groups in the project (Swedish-born, refugees, and survivors), or by people from these groups who were asked to write their life story. When the collected material was archived, all

62 M. Thor Tureby, To Hear with the Collection. Recontextualisation and Contextualization of Archived Interviews, "Oral History" 2013, Vol. 41(2), pp. 64-73; eadem, Svenskjudiska liv. Levnadsberättelser i skuggan av Förintelsen [Swedish-Jewish Lives. Life Stories in the Shadow of the Holocaust], "Svenska landsmål och svenskt folkliv. Tidskrift för talspråksforskning, folkloristik och kulturhistoria” 2019, Vol. 141, pp. 117-144; eadem, Memories, Testimonies and Oral History. On Collections and Research about and with Holocaust Survivors in Sweden, in: SOU 2020:21. Holocaust Remembrance and Representation: Documentation from a Research Conference, Norstedts Juridik AB, Stockholm 2020, pp. 67-92.

63 The "White Buses mission" refers to a program undertaken by the Swedish Red Cross and the Danish government in the spring of 1945 to rescue concentration camp inmates in areas under Nazi control and transport them to Sweden.

64 M. Thor Tureby, To Hear with the Collection...; eadem, Svenskjudiska...

65 Undated document for applications for funds, Nordiska museets arkiv, Judiska minnen D375:387.

66 Compare M. Thor Tureby, 'No, I Never Thought that We Were Different.' Vulnerability, Descriptive Discourses and Agency in the Archive, in: A. Öhrberg et al. (eds.), From Dust to Dawn. Archival Studies after the Archival Turn, Uppsala University Press, Uppsala 2021 (in print). 
the life stories were provided with a cover and an accession number. On the cover, information can be found about the type of main source included therein (the terms used are oral or written life story), how extensive it is (number of pages), if there are any attachments (such as cards, letters, photos, or other documents) as well as a review of the source (for example reflective, easy-to-read, concise, etc.). Also, personal data is noted: name, category (Swedish-born, refugee, or survivor), gender, date of birth, and place of residence. The cover also provides a short summary, together with a chronology that is divided into the pre-war years (place of birth, other places, family size, parents occupation, employment, other activities, Jewish affiliation); the war years (here the archivist responsible for compiling the material has written a short story of what happened to the person during the war years); followed by a chronological account of the post-war years (the social situation in 1945, the fate of the family, employment, other activities, family formation, Jewish affiliation, and other issues). The compilation of the material and the writing of the texts on the cover contributes to a homogenization of the material, but also creates a chronology of the individual life stories that follows the course of the war rather than the life course of the individual. Thus, the staff at the archive have created a narrative during the archivization process that can be understood as a hybrid between a life story and a story of the Second World War and the Holocaust.

The design of the archiving system, how the individual life stories were compiled and filed both separately but also together in the collection, the use of categories (Swedish-born, refugee, and survivor) and the use of accession numbers instead of the interviewees names when a registry for the collection was created, are all examples not only of how the archivists were part of and co-creators of the stories contained in the archives, but also of how the anonymization of the materials was practiced and implemented in the archivization process; reducing the individuals to numbers in order to protect them from a perceived antisemitic threat. ${ }^{67}$

In another study of 50 of the collected life-stories from individuals categorized as Swedish-born Jews, Thor Tureby was able to demonstrate that even though "Jewish Memories" was initiated and created to counter what was perceived as growing antisemitism and xenophobia in Swedish society during the 1990s, the Swedish-born Jews were constructed as non-Swedish and aliens during the interviewing and collection processes. ${ }^{68}$ For example, during the interviews the interviewees were asked questions regarding their alleged "Jewish appearances or manners" or how they understood themselves in relation to "ordinary" or "normal" Swedes. Previous research has argued that racial thinking about "Jews" and the use of antisemitic beliefs and stereotypes was an element in the creation of a mode of

67 Compare M. Thor Tureby, Svenskjudiska...; J.M. Schwartz, T. Cook, Archives, Records, and Power. The Making of Modern Memory, "Archival Science" 2002, Vol. 2(1), pp. 1-19.

68 M. Thor Tureby, 'No, I Never Thought that We Were Different'... 


\section{GENERAL ARTICLES}

Malin Thor Tureby and Kristin Wagrell

Swedish cultural and national identity and in different constructions of 'Swedishness' at the beginning of the 20th century. ${ }^{69}$ Thor Tureby's earlier study of "Jewish Memories" thus shows how this 'Othering' of Swedish Jews continued, to some extent, during the interviewing and archivization processes of the collection in the 1990s. The study also demonstrates how antisemitism in Sweden was understood in the 1990s as something that belonged to the past or was practiced by specific groups in society (young, angry neo-Nazis) and not as a prevailing discourse or construct in the society in general. ${ }^{70}$

This way of perceiving antisemitism and Jewish vulnerability also informed how ethical considerations were discussed during the creation of the collection. Even though we have not found any documents that specifically describe how the collecting and curating of the future collection was discussed in relation to ethics, we have identified a few documents indicating that a discussion about ethical aspects did take place. There are, for instance, copies of an interview contract and a form for informed consent that was drafted for the establishment of a Holocaust collection within the Jewish community's archive in Gothenburg. ${ }^{71}$ However, it does not appear that this informed consent form was copied, or that a similar form was used once the collection was carried out at the Nordic Museum. Instead, a document used for applying for external funding for the project stated that: "This project actualizes questions of ethics, for example personal integrity. The Nordic Museum has the right to classify documents as strictly secret. The principle will be applied whenever an informant so wishes". ${ }^{72}$ The same document states that:

The collected material - tapes, transcripts and autobiographical material will be kept in the archives of The Nordiska Museet. There are several different purposes; the material will be kept there long after the informant and people working with this project, and the people supporting it, are gone. The material will be available (provided that the informant gives his/her consent to researchers in the future). ${ }^{73}$

69 See, for example, L.M. Andersson, En jude är en jude är en jude... Representationer av "juden" i svensk skämtpress omkring 1900-1930 [A Jew is a Jew is a Jew... Representations of "Jews" in the Swedish Humor Press ca. 1900-1930], Nordic Academic Press, Lund 2000; R. Wright, The Visible Wall. Jews and Other Ethnic Outsiders in Swedish Film, Southern Illinois University Press, Carbondale, IL 1998.

70 M. Thor Tureby, 'No, I Never Thought that We Were Different'...

71 Göteborgs församlings arkiv för dokumentation av Förintelsen (febr. 1995) Överenskommelse and Om Intervjukontraktet, Nordiska museets arkiv, Judiska minnen D375:387. Projektets bakgrund. Mapp: Guidelines för intervjuer från Yad Vashem i Israel mm.

72 Judiska minnen- ett dokumentations- och forskningsprojekt / Jewish Memories - A Documentation and Research Project, p. 5, Nordiska museets arkiv, Judiska minnen D375:387. Projektets bakgrund. Mapp: underlag för ansökningar om fondmedel. This document has a Swedish and an English version. In the Swedish version of the document it is also stated that since the Nordic Museum is a foundation it is not subject to the general principle of public access (Swedish: offentlighetsprincipen), and that it can choose to classify documents as secret. See ibidem, p. 4.

73 Ibidem, p. 6. 
In the application for funding it is further stated that the Nordic Museum's contribution to the establishment of a Jewish Memory bank would be to "make it accessible to researchers and to the public". ${ }^{74}$ However, since the life stories in the collection were collected without informed consent from the participants, the collection remains inaccessible and more or less hidden from the public. As previously mentioned, all material from the project "Jewish Memories" is today protected by a 70-year secrecy clause and can only be accessed in compliance with specific rules that the museum curators have drafted on their own, and that are left to the interpretation of the archive director. Moreover, since the Nordic Museum chose not to collect informed consents, the archive director is also responsible for granting permission to access and/or use the collection. He or she grants or rejects written applications for studies and use of the material. Anyone wishing to study the material in the archive must state in writing the purpose of the study, their name and address, and identify themselves. Anyone who has been authorized to study the material must undertake in writing to comply with the permission rules for the collection of "Jewish Memories". These rules are:

1. The material may only be used for purposes specified in writing when writing the application for accessing the archive material.

2. Anyone who receives the archive material may not disclose any information in the material without permission.

3. Publication or publication of longer quotations, names, or other personal data requires the permission of the archive director. The archive director must ask the person who provided the material to give his/her consent before the publication. If the person cannot be reached, the decision is made by the archive manager.

4. The person studying the archive material may not contact persons who are represented in the material without these persons being first consulted by the archive manager/director.

5. The material may not be copied in any way without the permission of the archive manager/director. ${ }^{75}$

This ad hoc treatment of the material with regards to its accessibility is enabled by the fact that the Nordic Museum is run by a foundation. Even though a majority of its activities rely on government funding, the institution - the museum and the archive - exists outside of the legal framework that governs practices of secrecy and confidentiality at Swedish government institutions. Rather than having to abide by the principles of public access to information and secrecy, the Nordic Museum can make its collections confidential for as long as they see fit, making access subject to the reasoned opinion of whoever manages their holdings at the

74 Ibidem, p. 7.

75 Records of collected material. Project Jewish Memories, dated 1998-05-06, p. 2, Nordiska museets arkiv, Judiska minnen D375. 


\section{GENERAL ARTICLES}

Malin Thor Tureby and Kristin Wagrell

time. In combination, the 70-year secrecy clause, the specific rules formulated by the Museum, as well as the absence of informed consent present significant ethical problems with respect to any efforts to digitize the collection, as well as for any researcher who wishes to use the material in "Jewish Memories" for research. At the same time the question may be posed: Could digitization be understood as a method and a solution to the inaccessibility of this collection? We think the answer is yes, if digitization is not perceived simply as an act of replication, but as an act of creation that radically transforms the nature, accessibility, and use of the collections and the material they hold. We return to how this might be done in the final section of this article, but first we will discuss the creation of another collection: the "Memory Archive".

\section{The "Memory Archive" and the Practice of Confidentiality through Concealment}

Initially, the aim of the "Memory Archive" - carried out under the working title "The documentation project" by the Committee for Living History - resembled that of "Jewish Memories", with a focus on the victims of the Holocaust. However, as a project leader was appointed together with a special advisor and an expert group comprised of Swedish historians, an emphasis on the so-called "Swedish perspective" soon emanated. ${ }^{76}$ As Kristin Wagrell demonstrates in her doctoral dissertation, this perspective did not necessarily exclude the victims, but rather shifted the focus of the collection to the onlookers and bystanders since these groups were deemed to better reflect Sweden's historical connection to the Holocaust. ${ }^{77}$ The "Swedish perspective" was thus summarized as follows in a memo penned by the project leader, Eva Fried:

The idea of collecting testimonies from people who are not Holocaust survivors themselves is based on the belief that there is a need of information that can give life to historical facts regarding the Holocaust period. Although, for obvious reasons, the reports from the persecuted and the survivors are central in Holocaust studies, future investigators may be left with a number of important questions. In fact, many of these questions may be crucial in the understanding of the events during the days of the mass murder. Significant issues in this context are e.g. the roles of the non-persecuted, the bystanders, and the ordinary people. Which were the values, the reactions and the actions of people in Sweden, a bystander country? ${ }^{78}$

76 K. Wagrell, "Chorus of the Saved": Constructing the Holocaust Survivor in Swedish Public Discourse, 1943-1966, Linköping University Press, Linköping 2020, pp. 89-103.

77 Ibidem.

78 The documentation project within the frame of the Living History Project, Riksarkivet, Kommittén Forum för Levande historia med Projekt Levande Historia, Vol. 12, p. 2. 
Interestingly, the "Swedish perspective" was reinforced by the special advisor to the collection, Ingrid Lomfors, who also happened to be one of the project leaders for "Jewish Memories". There was thus a considerable overlap between the two collections with regards to the experts who affected their framing and direction.

As can be seen in the early documentation of the collection process for "Memory Archive", issues of secrecy and confidentiality were high on the acting committee's agenda. For example, in a memo issued before the collection process commenced, four "risks" connected with this future endeavour were articulated. The memo explained how important it was to be clear about how the future museum/Forum received or borrowed material from people, partly to protect the material but also to protect the people who donated or lent it out. ${ }^{79}$ To further emphasize the importance of this cautious stance toward potential contributors to the collection, the Nordic Museum was referred to as an example of an institution that was "very restrictive in their issuing of permission to study the material". 80

Because the committee conducting the collection of testimonies and objects was working under the Swedish Ministry of Culture, all documents and/or oral testimonies they received and collected would fall under the principle of public access to official documents. Yet, since the "documentation project" did not necessarily focus on "vulnerable" individuals such as Jewish camp survivors, one could assume that protection of the material should not have been as big of an issue as it had been for the collectors and archivers of "Jewish Memories". However, in a memo from 2001, when the "Swedish perspective" had been firmly established and interview categories had already been decided upon, there was still considerable concern for the protection of the material. For instance, in one memo it was stated that "the personal data in the witness accounts that are given to the committee is deemed to be highly sensitive". ${ }^{11}$ Even though it was never explained why the data was deemed so sensitive, it can be deduced from the phrasings in other documents that the committee was referring to the fact that these voices countered those who wished to deny the Holocaust. Furthermore, in the plan for their collection the purpose was framed through a reiteration of Persson's initial aim for "Living History": "Prime Minister Göran Persson promised in the parliamentary debate of June 1997 to produce information about 'what happened during the Second World War and the view of human beings that informed the Holocaust"'. ${ }^{82}$ Even though the expressed purpose was never to counter neo-Nazism, this problem representation continued to inform

\footnotetext{
79 Insamling av Material med anknytning till Förintelsen (dated 1999-06-14), Riksarkivet, Kommittén Forum för Levande historia med Projekt Levande Historia, Vol. 12, p. 2

80 Ibidem ("Nordiska museet är idag mycket restriktiva med att ge tillstånd till att undersöka materialet").

81 Sekretess enligt $3 \S$ sekretessförordningen (1980: 657), p. 1, Riksarkivet, Kommittén Forum för Levande historia med Projekt Levande Historia, Vol. 12.

82 Planering av dokumentationsprojektet år 2001 för Forum för levande historia, p. 2, Riksarkivet, Kommittén Forum för Levande historia med Projekt Levande Historia, Vol. 12.
} 


\section{GENERAL ARTICLES}

Malin Thor Tureby and Kristin Wagrell

every aspect of planning for the future Forum. Ultimately, the collection was aimed at young people - those who Persson and many before him had claimed were particularly sensitive to the spread of neo-Nazi and racist propaganda.

The committee responsible for the collection therefore tried, together with the project leader, to acquire special permission for the protection of the collection under Article 3 of the Secrecy Act of 1980 (replaced by the Public Access to Information and Secrecy Act in 2009), which stated that "secrecy applies, following a government agency's investigations, to information that relates to an individual person's personal or economic relations and which can be related back to that individual person". ${ }^{83}$ A month later however, the application for secrecy was revoked, without any further explanations as to why the protection was no longer deemed to be necessary. ${ }^{84}$ Hence the question arises: Why did the committee abandon their plans to protect the collection?

Perhaps the answer to this question can be found in the discussion concerning another separate, yet interrelated, collection of Holocaust testimonies which was part of the planning process for the "documentation project". Although it constituted its own separate collection, the initiative for "Roma Memories" was initially planned to be a part of the future holdings of the Living History Forum. A special investigator, activist, and former psychologist, Ingrid Schiöler, was appointed to examine whether there were enough Roma survivors in Sweden who wished to contribute to a collection of testimonies. In her report, submitted to the committee in 1999, Schiöler explained that there were approximately 300 Roma survivors living in the Gothenburg area alone, and that she was in contact with about a 100 of these individuals. She also emphasized the importance of interviewing the older generation - who were adults during the Holocaust - both because of their immanent passing but also because many of them were illiterate and could not record their own testimonies for posterity. ${ }^{85}$ The collection was thus considered an urgent matter that needed to commence sooner rather than later. Also, throughout the planning process for the "Memory Archive" it was repeatedly stated that all experts and advisors agreed that the Roma should be a prioritized group in the future collection. ${ }^{86}$ Yet, when the collection was about to begin, it was stopped in its tracks

83 Sekretess enligt 3 § sekretessförordningen..., p. 1; Föreskrifter med stöd av 9 kap. 4 § Sekretesslagen, $3 \S$ ("Sekretess gäller, i den utsträckning som anges i denna paragraf, i följande av myndighet utförda undersökningar, för uppgifter som avser en enskilds personliga eller ekonomiska förhållanden och som kan hänföras till den enskilde").

84 Angående ansökan om ändring i sekretessförordningen (ärende JU 2001-2525), Riksarkivet, Kommittén Forum för Levande historia med Projekt Levande Historia, Vol. 12.

85 Intervjuer med romer som överlevt Förintelsen, p. 1, Riksarkivet, Kommittén Forum för Levande historia med Projekt Levande Historia, Vol. 13. See also Bilaga till kontrakt mellan Levande Historia och Ingrid Schiöler.

86 Planering av dokumentationsprojektet insamling av vittnesmål och dokumentation för Forum för levande historia; Verksamhetsplan för kommittén Forum för levande historia; Planering av dokumentationsprojektet år 2001 för Forum för levande historia, Riksarkivet, Kommittén Forum för Levande historia med Projekt Levande Historia, Vols. 12, 13. 
because there was no way of protecting the material. In the notes from a meeting between Fried and Jonas Stertman from the Swedish Committee on Justice (Justitieutskottet, JU), it was written in capital letters that "[T]HE MATERIAL CAN NEVER BE SUBMITTED TO THE NATIONAL ARCHIVES AS IT WILL THEN BE PUBLIC PROPERTY" ${ }^{87}$ Since all government documents need to be submitted for archiving at the Swedish National Archives, the committee was forced to change their plans for the "Roma Memories" collection.

A final effort was made to make the collection happen through an informal request to the Nordic Museum. The idea was that since the Nordic Museum was a foundation, they could create a collection and protect it in the same manner as they had done with "Jewish Memories". In their reply, the Nordic Museum did not completely close the door to negotiation, but underlined the fact that the collection would have to be externally funded as it did not fit into the Museum's own budget. ${ }^{88}$ With this response the plans for a collection of Roma testimonies from the Holocaust died and the endeavour never left the planning stage.

Since the "Memory Archive" largely focused on rescue workers and bystanders to the Holocaust, and only contained a smaller portion of testimonies given by Jewish and Roma survivors, this collection commenced with the spectre of public access looming over it. However, other strategies were adopted in order to limit access to the collection. The material - approximately 100 one-hour long video-recorded interviews - has never been organized, indexed, or catalogued. Apart from the book De glömmer det aldrig (They Never Forget) - which presented some of the material and was published in 2003 - no further efforts have been made to advertise its existence. Instead it is kept on two unassuming hard-drives, one at the Living History Forum in Old Town, Stockholm, and the other at the Swedish National Archives.

Just as in the case of "Jewish Memories", these practices create significant problems for public access to and studies of the "Memory Archive". The material is not searchable, and the quality of the recordings is adequate at best. Even more problematic, however, is the fact that an important part of the envisioned collection - "Roma Memories" - was abandoned based on the fact that it could not be protected. Here, the problem representation underpinning the collection efforts remains the threat of neo-Nazism and xenophobia. This problematization of Jewish and Roma vulnerability led to the concealment of one collection, as well as the abandonment of another with the potential to be unique in its kind, as few survivor testimonies from the Roma exist in a Swedish context. Furthermore, rather than asking the prospective interview subjects of the Roma collection whether they would

\footnotetext{
87 Anteckningar från diskussion med Jonas Stertman JU om sekretess för materialet rörande vittnesmål, Romer, Riksarkivet, Kommittén Forum för Levande historia med Projekt Levande Historia, Vol. 12.

88 Letter to Eva Fried from Johan Åkerlund \& Cecilia Hammarlund-Larsson, Riksarkivet, Kommittén Forum för Levande historia med Projekt Levande Historia, Vol. 12.
} 


\section{GENERAL ARTICLES}

Malin Thor Tureby and Kristin Wagrell

like to participate in a collection even though they could not be anonymized, the collectors merely assumed that they knew the Roma precarity better than these individuals themselves. Their vulnerability was thus defined and established without any regards to their own ability and/or willingness to resist the anti-gypsy and xenophobic forces that attempted to suppress their voices. Thus, just as Löwander argues with regard to the news discourse on racism and anti-racism in the early 1990s, the Roma were not allowed any space to speak about what made them vulnerable, but were simply labelled as such by others around them.

\section{Beginning to Bridge the Gap: Digitization as Transformation}

Digitization, anonymity, and representation are deeply ethical arenas, which require that the actors and institutions that plan, collect, archive, and use cultural heritage collections adopt a reflective stance and consider the multiple, often conflicting, ways of treating "vulnerable" information about interview subjects. In this section we discuss how the problems that have arisen in the gap between cultural heritage practice and public policy on digitization can be bridged by reconceptualizing digitization as transformation. In this article we have challenged some common sense ideas about anonymization as "ethical", as well as notions of what constitutes vulnerability, and how "vulnerable" subjects can be protected. We have shown how different kinds of vulnerability relating to "Jewishness" and being Roma were created in the processes of collecting and curating stories from survivors in two Holocaust collections established during the 1990s in Sweden.

Returning to Bacchi's questions, the problem representation of Jewish and Roma vulnerability in large-scale institutional archival projects in Sweden has been based on the assumption that these individuals should and indeed can be protected from antisemitism, anti-gypsyism and xenophobia by keeping their names, stories, and personal details concealed from threatening elements in society. With regards to the question of discursive effects, this protection invariably leads to the entrenchment of already established perceptions of the Jewish and Roma minorities as passive victims and as the "Other" in Swedish society. Since certain forms of antisemitism are pervasive and normalized throughout all segments of society, Swedish Jews and Roma live in a constant state of vulnerability, and cannot, therefore, be wholly protected from prejudice or harmful notions about their nature and ways of life. This does not mean, however, that their stories should not be treated with care or that survivors should not have the "infrastructural support" to speak about their lives and experiences before, during, and after the Holocaust.

Inspired by another ongoing research project about and in collaboration with Jewish women in Sweden, where Thor Tureby found that many of the women who chose to participate in the project wanted their names to be used in research publications, we also attempt to disrupt and question the prevailing public discourse on racism, neo-Nazism, and antisemitism, as well as the juridical discourses on vulner- 
ability, Jewishness, and research ethics. ${ }^{89}$ Not only does the women's willingness to participate in the research project and to be named in publications resulting from the project challenge existing laws on how to conduct research in an ethical way through anonymization, but it also disputes conceptions of who is vulnerable and therefore in need of protection..$^{90}$ Furthermore, our present study, as well as the ongoing project with and about Jewish women's stories, show the importance of shared authority and having a participatory process when creating and curating collections that relate to difficult subjects such as the Holocaust. In oral history, the term "shared authority" is today frequently used to refer to interviews as a collaborative process, where the interviewer and interviewee work together to contribute to the historical record..$^{91}$ The term has been used to explore how authorship and interpretive authority are connected. By adopting such a perspective, the researcher acknowledges that authority is not something that is given, but that it is already there. The shared authority thus shapes the meaning(s) of the record produced. We suggest that the thoughts underpinning the theories of shared authority might also influence the curation and transformation of an analogue archive to a digital archive.

Because the Nordic Museum never obtained informed consent from the participants of "Jewish Memories", these will now have to be collected in retrospect. We suggest that the creation of a participatory digital archive from a non-participatory analogue archive will provide a space for discussion and negotiation, as well as a platform for power over one's own history. ${ }^{92}$ Following Butler's contention that "all action requires support and that even the most punctual and seemingly spontaneous act implicitly depends on an infrastructural condition that quite literally supports the acting body", we suggest that the enfranchisement of groups that have been labelled "vulnerable" can lead to new ways of reclaiming one's own history. ${ }^{93}$ The inclusion of the archival participants into the digitization process is not merely an act of supporting the right to articulate one's own history, but also a way of understanding how collections in archives as the basis of knowledge production can be transformed when they become participatory. In line with Jacques Derrida's now famous contention that "the archivization produces

89 Compare M. Thor Tureby, Oral History and Standardized Research-Ethics Regulations. Epistemological and Methodological Reflections from a Newly Started Oral History Project with Jewish Women in Sweden, paper presented at IOHA 2018 MEMORY \& NARRATION, The XX International Oral History Association Conference, 18-21 June 2018, https://www.jyu.fi/en/congress/ioha2018/program-1/slotti-2 [accessed: 16.11.2020].

90 Compare M. Thor Tureby, Svenskjudiska...

91 M. Frisch, A Shared Authority: Essays on the Craft and Meaning of Oral and Public History, State University of New York Press, Albany 1990.

92 Compare A.J. Gilland, S. McKemmish, The Role of Participatory Archives in Furthering Human Rights, Reconciliation and Recovery, "Atlanti” 2014, Vol. 24(1), pp. 79-88.

93 J. Butler, Rethinking Vulnerability..., p. 19. 


\section{GENERAL ARTICLES}

Malin Thor Tureby and Kristin Wagrell

as much as it records the event"94, we argue that the Holocaust collection actually changes when participants are engaged in the digitization process. Rather than merely translating already-existing material from analogue to digital, the new participants - whether they are the original interview subjects or second/third generation survivors - can help produce new meta-data about the collection; they can contribute novel insights on indexing and cataloguing; and they can add new perspectives on whom the digital archive should be aimed toward. Instead of translating the archive, they would be transforming it.

Practicing shared authority when digitizing the collections would thus help bridge the gap between cultural heritage practice and public policy on digitization. By developing participatory and ethical archiving/digitization methods that actually engage with the issues faced by humanities and social science scholars, cultural heritage institutions can contribute to the collection, preservation, and accessibility of material from groups that have been marginalized from the public discourse. By including previously marginalized groups in archiving, collecting, and digitization, cultural heritage institutions could contribute to an actual increase in public and citizen involvement in the cultural heritage sector.

\section{Conclusions}

In this article we have attempted to identify and problematize the gap that currently exists between the practices of cultural heritage institutions and public policy on digitization, research ethics, and open access in a Swedish context. Guided by Bacchi's "What's the problem represented to be" approach, the representation of the problem of a neo-Nazi threat was identified, together with the underlying assumption that this threat was anomalous in the Swedish social body and could be mitigated by protective measures such as educating the young, collecting testimonies from the time of the Holocaust, and anonymizing these voices by making parts of the material confidential. Here, a paradox appeared and the solution to the problem became another problem in itself: the testimonies were supposed to counter Holocaust denial and neo-Nazi propaganda, yet no one could access them. The anxieties caused by the notion that the material would fall into the wrong hands even prevented the collection of unique and important stories that could have been contributed by Roma survivors of the Holocaust. Rather than ask the prospective interview subjects whether they were willing to take the risk of exposing their names (and faces), the Committee for Living History decided that the risk was one not worth taking.

These protective measures paradoxically undermine what/who they are meant to protect. Not only do they prevent public institutions from following governmental directions on digitization and access, but perhaps more importantly,

94 J. Derrida, Archive Fever. A Freudian Impression, The University of Chicago Press, Chicago-London 1996, p. 17. 
they obstruct any resistance from within the groups that are under protection. Historically, activists from the Jewish and Roma communities have gone to great lengths, sometimes risking their lives, in order to spread the word on how discrimination, persecution, mass violence, and genocide have affected and continue to affect people around the world. However, without the "infrastructural support" (media attention, government funding, and institutional praxis) to resist oppression and violence, their resistance becomes weaker as their freedom to act in resistance against the hardships facing them diminishes.

In our research we have only just begun to explore these questions. Thus, identifying the problems and the problem representations is just a first step in a longer process of trying out new avenues for bridging the gap between cultural heritage practice and government policy. Based on previous studies of shared authority and participatory archiving, we suggest that these methods could ensure that those groups who have been defined as vulnerable, and whose precarity can clearly be seen through the ways in which their freedoms are limited, would have an "infrastructural support" to rely on. Rather than suppress and conceal their voices, shared authority and participatory archiving can help transform analogue collections into digital spaces where more than the original objects and stories can find a place and be heard.

\section{References}

Adenfelt M., Larsson I., Edholm M., Digitaliserat kulturarv - för demokrati och positiv samhällsutveckling. En förstudie [Digitized Cultural Heritage - For Democracy and Positive Social Change], Digisam, Stockholm 2020.

Agostinho D. et al., Uncertain Archives: Approaching the Unknowns, Errors, and Vulnerabilities of Big Data through Cultural Theories of the Archive, "Theories of the Archive, Surveillance and Society" 2019, Vol. 17(3-4).

Allwork L., Holocaust Remembrance Between the National and the Transnational: The Stockholm International Forum and the First Decade of the International Task Force, Bloomsbury Publishing, London 2015.

Andersson L.M., En jude är en jude är en jude... Representationer av "juden" i svensk skämtpress omkring 1900-1930 [A Jew is a Jew is a Jew... Representations of "Jews" in the Swedish Humor Press ca. 1900-1930], Nordic Academic Press, Lund 2000.

Angående ansökan om ändring i sekretessförordningen (ärende JU 2001-2525), Riksarkivet, Kommittén Forum för Levande historia med Projekt Levande Historia, Vol. 12.

Anteckningar från diskussion med Jonas Stertman JU om sekretess för materialet rörande vittnesmål, Romer, Riksarkivet, Kommittén Forum för Levande historia med Projekt Levande Historia, Vol. 12.

Apperly E., "Stumbling Stones": A Different Vision of Holocaust Remembrance, "The Guardian", 18 February 2019, https://www.theguardian.com/cities/2019/feb/18/stumbling-stones-a-different-vision-of-holocaust-remembrance [accessed: 30.09.2020].

Arolsen Archives, Help Us Build a Unique Digital Monument, https://arolsen-archives.org/en/ learn-participate/interactive-archive/everynamecounts/ [accessed: 28.09.2020]. 


\section{GENERAL ARTICLES}

Malin Thor Tureby and Kristin Wagrell

Bacchi C., Analysing Policy. What's the Problem Represented to Be?, Pearson, Frenchs Forest, N.S.W. 2009.

Bacchi C., Goodwin S., Poststructural Policy Analysis: A Guide to Application, Palgrave Macmillan, London-New York 2016.

Bachner H., Återkomsten. Antisemitism i Sverige efter 1945 [The Return. Anti-Semitism in Sweden after 1945], Natur \& Kultur, Stockholm 1999.

Bachner H., Political Cultures of Denial? Antisemitism in Sweden and Scandinavia, in: L. Rensman, J.H. Schoeps (eds.), Politics of Resentment: Antisemitism and Counter-Cosmopolitanism in the European Union, Brill, Leiden 2011.

Bilaga till kontrakt mellan Levande Historia och Ingrid Schiöler, Riksarkivet, Kommittén Forum för Levande historia med Projekt Levande Historia, Vol. 13.

Butler J., Precarious Life. The Powers of Mourning and Violence, Verso, London-New York 2006.

Butler J., Rethinking Vulnerability in Resistance, in: J. Butler, Z. Gambetti, L. Sabsay (eds.), Vulnerability in Resistance, Duke University Press, Durham 2016.

De Jong S., The Witness as Object. Video Testimonies in Memorial Museums, Berghahn Books, New York 2018.

Derrida, J., Archive Fever. A Freudian Impression, The University of Chicago Press, Chicago-London 1996.

Etikprövningsmyndigheten, Vetting the Ethics of Research Involving Humans, http://www.epn. se/en/start/ [accessed: 14.08.2020].

Frisch M., A Shared Authority: Essays on the Craft and Meaning of Oral and Public History, State University of New York Press, Albany 1990.

Gilland A.J., McKemmish S., The Role of Participatory Archives in Furthering Human Rights, Reconciliation and Recovery, "Atlanti" 2014, Vol. 24(1).

Göteborgs församlings arkiv för dokumentation av Förintelsen (febr. 1995) Överenskommelse and Om Intervjukontraktet, Nordiska museets arkiv, Judiska minnen D375:387. Projektets bakgrund. Mapp: Guidelines för intervjuer från Yad Vashem i Israel mm.

Graaf H., How Do Mainstream Media Communicate Minority Media? A Difference-Theoretical Study on Radio Islam and AYPA-TV, Södertörns högskola, Huddinge 2009.

Greenspan H., On Listening to Holocaust Survivors. Beyond Testimony, 2nd ed., Paragon House, St. Paul, MN 2010.

Insamling av Material med anknytning till Förintelsen (dated 1999-06-14), Riksarkivet, Kommittén Forum för Levande historia med Projekt Levande Historia, Vol. 12.

Intervjuer med romer som överlevt Förintelsen, Riksarkivet, Kommittén Forum för Levande historia med Projekt Levande Historia, Vol. 13.

Judiska minnen- ett dokumentations- och forskningsprojekt / Jewish Memories - A Documentation and Research Project, Nordiska museets arkiv, Judiska minnen D375:387. Projektets bakgrund. Mapp: underlag för ansökningar om fondmedel.

Kulturdepartementet, SOU 2019:58. Härifrån till evigheten: en långsiktig arkivpolitik för förvaltning och kulturarv [From Here to Eternity: A Long-Term Archiving Policy for Management and Cultural Heritage], Norstedts Juridik, Stockholm 2019.

Lag (2003:460) om etikprövning av forskning som avser människor [Act Concerning the Ethical Review of Research Involving Humans], Svensk författningssamling 2003:460. 
Lag (2018:218) med kompletterande bestämmelser till EU:s dataskyddsförordning [Act Containing Supplementary Provisions to the EU General Data Protection Regulation], Svensk författningssamling 2018:218.

Lange A. et al., Utsatthet för etniskt och politiskt relaterat hot $\mathrm{mm}$., spridning av rasistisk och antirasistisk propaganda samt attityder till demokrati mm. bland skolelever [Exposure to Ethnically and Politically Motivated Violence, the Spread of Racist and Anti-Racist Propaganda, and Attitudes to Democracy Among School Youth], Ceifo, Stockholm 1997.

Le Roux C., Oral History Research Ethics: Should Anonymity and Confidentiality Issues Be Dealt with on Their Own Merit?, "Africa Education Review" 2016, Vol. 12(4).

Letter to Eva Fried from Johan Åkerlund \& Cecilia Hammarlund-Larsson, Riksarkivet, Kommittén Forum för Levande historia med Projekt Levande Historia, Vol. 12.

Levinas E., Totality and Infinity. An Essay on Exteriority, Duquesne University Press, Pittburg 1969.

Lööw H., Nazismen i Sverige, 1980-1999 - den rasistiska undergroundrörelsen: musiken, myterna, riterna [Nazism in Sweden, 1980-1999 - The Racist Underground Movement: Music, Myths, Rites], Ordfront förlag, Stockholm 2000.

Löwander B., Rasism och antirasism på dagordningen - studier av televisionens nyhetsrapportering i början av 1990-talet [Racism and Anti-Racism on the Agenda - Studies of Television News Reporting in the Early 1990s], "Sociologisk forskning" 1998, Vol. 35(3-4).

Minutes of the Riksdag 1996/97:119, 12 June 1997, p. 22, https://data.riksdagen.se/fil/62A0CA5E-31EE-4431-BE69-BA7A41688D2A [accessed: 26.10.2020].

Moore N., The Politics and Ethics of Naming: Questioning Anonymisation in (Archival) Research, "International Journal of Social Research Methodology" 2012, Vol. 15(4).

Nick I.M., Personal Names, Hitler, and the Holocaust. A Socio-Onomastic Study of Genocide and Nazi Germany, Lexington Books, Lanham, MD 2019.

Offentlighets- och sekretesslag (2009:400) [Public Access to Information and Secrecy Act], Svensk författningssamling 2009:400.

Personuppgiftslag (1998:204) [Personal Data Act], Svensk författningssamling 1998:204.

Planering av dokumentationsprojektet år 2001 för Forum för levande historia, Riksarkivet, Kommittén Forum för Levande historia med Projekt Levande Historia, Vol. 12.

Planering av dokumentationsprojektet insamling av vittnesmål och dokumentation för Forum för levande historia, Riksarkivet, Kommittén Forum för Levande historia med Projekt Levande Historia, Vols. 12, 13.

Records of collected material. Project Jewish Memories, dated 1998-05-06, p. 2, Nordiska museets arkiv, Judiska minnen D375.

Regeringen, Regeringsförklaringen [Governmental Declaration], 21 January 2019, https:// www.regeringen.se/48f68a/contentassets/6e0630547665482eaf982c4777f42f85/ regeringsforklaringen-2019.pdf [accessed: 15.01.2020]; English summary: http://www. sou.gov.se/mof/in-english/ [accessed: 28.09.2020].

Schwartz J.M., Cook T., Archives, Records, and Power. The Making of Modern Memory, "Archival Science" 2002, Vol. 2(1).

Sekretess enligt 3 § sekretessförordningen (1980: 657), Riksarkivet, Kommittén Forum för Levande historia med Projekt Levande Historia, Vol. 12.

Sekretesslag (1980:100) [Secrecy Act], Svensk författningssamling 1980:100. 


\section{GENERAL ARTICLES}

Malin Thor Tureby and Kristin Wagrell

Shandler J., Holocaust Memory in the Digital Age. Survivors' Stories and New Media Practices, Stanford University Press, Stanford, CA 2017.

Shenker N., Reframing Holocaust Testimony, Indiana University Press, Bloomington, IN 2015.

The documentation project within the frame of the Living History Project, Riksarkivet, Kommittén Forum för Levande historia med Projekt Levande Historia, Vol. 12.

Thor Tureby M., Makten över kunskapsproduktionen. Den institutionaliserade etikprövningen och humanistisk och kulturvetenskaplig forskning [The Power over Knowledge Production. Institutionalized Ethical Vetting and Humanistic and Cultural Studies], "Kulturella Perspektiv. Svensk etnologisk tidskrift" 2019, Vol. 28(1-2).

Thor Tureby M., Memories, Testimonies and Oral History. On Collections and Research about and with Holocaust Survivors in Sweden, in: SOU 2020:21. Holocaust Remembrance and Representation: Documentation from a Research Conference, Norstedts Juridik AB, Stockholm 2020.

Thor Tureby M., 'No, I Never Thought that We Were Different.' Vulnerability, Descriptive Discourses and Agency in the Archive, in: A. Öhrberg et al. (eds.), From Dust to Dawn. Archival Studies after the Archival Turn, Uppsala University Press, Uppsala 2021 (in print).

Thor Tureby M., Oral History and Standardized Research-Ethics Regulations. Epistemological and Methodological Reflections from a Newly Started Oral History Project with Jewish Women in Sweden, paper presented at IOHA 2018 MEMORY \& NARRATION, The XX International Oral History Association Conference, 18-21 June 2018, https://www.jyu.fi/en/ congress/ioha2018/program-1/slotti-2 [accessed: 16.11.2020].

Thor Tureby M., Svenskjudiska liv. Levnadsberättelser i skuggan av Förintelsen [Swedish-Jewish Lives. Life Stories in the Shadow of the Holocaust], "Svenska landsmål och svenskt folkliv. Tidskrift för talspråksforskning, folkloristik och kulturhistoria" 2019, Vol. 141.

Thor Tureby M., To Hear with the Collection. Recontextualisation and Contextualization of Archived Interviews, "Oral History" 2013, Vol. 41(2).

Undated document for applications for funds, Nordiska museets arkiv, Judiska minnen D375:387.

USC Shoah Foundation's Visual History Archive, Terms of Use, https://vhaonline.usc.edu/ TermsOfUse [accessed: 09.10.2020].

Verksamhetsplan för kommittén Forum för levande historia, Riksarkivet, Kommittén Forum för Levande historia med Projekt Levande Historia, Vols. 12, 13.

Wagrell K., "Chorus of the Saved": Constructing the Holocaust Survivor in Swedish Public Discourse, 1943-1966, Linköping University Press, Linköping 2020.

WMA Declaration of Helsinki - Ethical Principles for Medical Research Involving Human Subjects, adopted in June 1964, https://www.wma.net/policies-post/wma-declaration-of-helsinki-ethical-principles-for-medical-research-involving-human-subjects/ [accessed: 29.11.2020].

Wright R., The Visible Wall. Jews and Other Ethnic Outsiders in Swedish Film, Southern Illinois University Press, Carbondale, IL 1998.

Yad Vashem, Hall of Names, https://www.yadvashem.org/archive/hall-of-names.html [accessed: 30.09.2020].

Yad Vashem, Names Recovery Project, https://www.yadvashem.org/remembrance/namesrecovery-project/about.html [accessed: 30.09.2020].

Yad Vashem, Shoah Victims' Names, https://www.yadvashem.org/archive/hall-of-names/ shoah-victims-names.html [accessed: 30.09.2020]. 